\title{
USO E CONSERVAÇÃO DAS ÁREAS DE PRESERVAÇÃO PERMANENTE E DE RESERVA LEGAL POR MORADORES DO ASSENTAMENTO BOA VISTA, PONTA PORÃ, MS
}

\author{
Use and conservation of permanent preservation and legal reserve areas by \\ residents of the Boa Vista Settlement, Ponta Porã, MS
}

\author{
Leandro Lopes Miranda \\ Universidade Federal da Grande Dourados - UFGD \\ le lopes.miranda@hotmail.com \\ Roberto Lobo Munin \\ Universidade Federal da Grande Dourados - UFGD \\ robertomunin@ufgd.edu.br
}

\section{Recebido em 29/11/2020 \\ Aceito em 18/12/2020}

RESUMO: Os assentamentos rurais devem ser estruturados com base em princípios socioambientais que promovam a integração sociedade-natureza, de maneira que se estabeleça a agricultura camponesa de uma forma social, econômica e ambientalmente justa e sustentável. Entretanto, muitos moradores acabam aderindo à produção de commodities, que muitas vezes avança sobre Áreas de Preservação Permanente (APP) e de Reserva Legal (RL). Esse trabalho teve como objetivo investigar o uso e conservação das APPs e RLs pelos moradores do Assentamento Boa Vista, município de Ponta Porã, Mato Grosso do Sul. Avalia também o uso de agrotóxicos pelas famílias e em quais atividades produtivas eles são empregados. A maioria dos moradores entrevistados $(73 \%)$ afirmou não saber quais atividades produtivas são permitidas de serem desenvolvidas nas áreas de APP e RL. Apesar disso, 46\% afirmaram desenvolver algum tipo de atividade nessas áreas, sendo que a apicultura foi apontada por $27 \%$, a agricultura por $4 \%$, e $15 \%$ não quiseram dizer qual atividade produtiva desenvolve nas áreas de APP e RL. Uma parte significativa dos proprietários (42\%) utiliza agrotóxicos, empregados principalmente no cultivo da soja, sendo o glifosato o mais utilizado. Os resultados do estudo evidenciam um cenário onde boa parte dos moradores produzem soja com o emprego de agrotóxicos ou arrendam parte da área de seus lotes para que terceiros a produzam. Este modelo de cultivo de monocultura coloca em risco a soberania alimentar da comunidade, uma vez que diminui drasticamente o espaço para o cultivo diversificado de alimentos saudáveis, livres de agrotóxicos, gerando fortes impactos socioambientais.

Palavras-chave: Agrotóxicos; Arrendamento de terra; Desmatamento; Commodities; Percepção ambiental.

\begin{abstract}
Rural settlements must be structured based on socioenvironmental principles that promote society-nature integration, so that peasant farming is established in a socially, economically and environmentally just and sustainable manner. However, many residents end up adhering to the production of commodities, which often advances over Areas of Permanent Preservation (APP) and Legal Reserve (LR). This work aimed to investigate the use and conservation of APPs and RLs by the residents of the Boa Vista settlement, municipality of Ponta Porã, Mato Grosso do Sul state. It also assesses the use of pesticides by families and in which productive activities they are employed. Most of the interviewed residents (73\%) stated that they do not know which productive activities can be developed in the areas of APP and LR. Despite this, $46 \%$ said they developed some type of activity in these areas, with beekeeping being mentioned by $27 \%$, agriculture by $4 \%$, and $15 \%$ did not want to say which productive activity they develop in the areas of APP and LR. A significant part of the owners (42\%) use pesticides, mainly in the cultivation of soybeans, with glyphosate being the most used one. The
\end{abstract}


USO E CONSERVAÇÃO DAS ÁREAS DE PRESERVAÇÃO PERMANENTE E DE RESERVA LEGAL POR MORADORES DO ASSENTAMENTO BOA VISTA, PONTA PORÃ, MS

results of the study show a scenario where a good part of the residents produce soybeans with the use of pesticides or lease part of the area of their lots for third parties to produce. This monoculture production model puts the community's food sovereignty at risk, as it drastically reduces the space for the diversified cultivation of healthy and pesticides free food, generating strong socio-environmental impacts.

Keywords: Pesticides; Land leasing; Deforestation; Commodities; Environmental perception.

\section{INTRODUÇÃO}

A criação de assentamentos rurais da reforma agrária no Brasil é pautada pela necessidade da luta social pela terra e pela permanência nela (TERRA, 2009; CAMACHO; CUBAS, 2011). Esses assentamentos devem ser estruturados com base em princípios socioambientais que promovam a perfeita integração sociedadenatureza, de maneira que se estabeleça a agricultura familiar de uma forma social, econômica e ambientalmente justa e sustentável. Devem prezar pela recuperação da identidade camponesa e pelo desenvolvimento de um modelo produtivo e de relações de trabalho que assegurem o direito a uma vida digna no campo, onde as famílias possam permanecer e cultivar sua cultura tradicional em seu território (TERRA, 2009; CAMACHO, 2015; CAVALCANTE et al., 2019; ALMEIDA et al., 2020). O modelo produtivo agroecológico é apontado como o ideal para que esses objetivos se concretizem, uma vez que estabelece relações humano-humano e humano-natureza mais equilibradas e justas do que o modelo atual do agronegócio brasileiro (PETERSEN, 2012; SANTOS; CHALUB-MARTINS, 2012; CAMACHO, 2015). No entanto, muitos moradores de assentamentos rurais acabam por seguir o modelo do agronegócio, aderindo à produção de commodities (e.g. soja, milho, algodão, canade-açucar), seja através da produção própria ou do arrendamento de parte da área do lote para que terceiros o produzam, o que resulta em um intenso processo de degradação socioambiental nesses assentamentos (TERRA, 2009; CAMACHO; CUBAS, 2011; ALMEIDA et al., 2020).

A produção de commodidites geralmente está associada ao uso de uma variedade de agrotóxicos, incluindo inseticidas, herbicidas e fungicidas (COSMANN; DRUNKLER, 2012). Dentre esses, o glifosato se destaca como o agrotóxico mais utilizado no Brasil (AGROFIT, 2020), especialmente na produção da soja, cuja função é eliminar plantas "daninhas" que possam competir por recursos e reduzir a produtividade das culturas. Esse herbicida é utilizado em associação com cultivares de soja transgênicas resistentes ao glifosato (conhecidas pelo termo em inglês Roundup Ready), e em 2012 a área cultivada com essas variedades transgênicas já representava $85 \%$ da área total de produção de soja no país, atingindo mais de 21 milhões de hectares (PINTO et al,. 2016). Em 2015, o glifosato foi apontado como um composto químico potencialmente cancerígeno pela Agência Internacional de Pesquisa sobre o Câncer (em inglês, International Agency for Research on Cancer - IARC), o que provocou uma onda de discussão e de iniciativas governamentais e não governamentais em várias regiões do mundo com o objetivo de banir o uso desse agrotóxico (CRESSEY, 2015). Nesse mesmo ano o Ministério Público Federal do Brasil reforçou uma solicitação que já havia sido feita em 2008 à Agência Nacional de Vigilância Sanitária (ANVISA) para a 
USO E CONSERVAÇÃO DAS ÁREAS DE PRESERVAÇÃO PERMANENTE E DE RESERVA LEGAL POR MORADORES DO ASSENTAMENTO BOA VISTA, PONTA PORÃ, MS

reavaliação toxicológica do glifosato e de outros sete agrotóxicos para um nível mais tóxico e perigoso do que 0 atual. Pedia ainda o banimento desses químicos do mercado até que fossem concluídas as análises de toxicidade. No entanto, em 2019 a ANVISA liberou a venda do glifosato no país.

Além dos riscos à saúde humana, o uso de agrotóxicos é considerado altamente perigoso ao ambiente, podendo reduzir a biodiversidade e afetar negativamente o funcionamento dos ecossistemas terrestres e aquáticos (GRAYMORE et al., 2001; RELYEA, 2005; BEKETOV et al., 2013; BELCHIOR et al., 2014; AMÉRICO et al., 2015; NEWMAN et al., 2016). Além da redução da biodiversidade associada ao uso intensivo de agrotóxicos, a simplificação da paisagem, peculiar ao cultivo de monoculturas, também afeta negativamente a biodiversidade e o equilíbrio e funcionamento dos ecossistemas, favorecendo o surgimento de "pragas", o que resulta em uma maior necessidade de intervenção humana (e.g uso de agrotóxicos e fertilizantes) no manejo das lavouras (ALTIERI, 2004). O cultivo de monoculturas avança agressivamente nos diversos biomas brasileiros, causando degradação e desmatamento de extensas áreas florestais nativas, inclusive em áreas de proteção ambiental.

No contexto dos assentamentos rurais da reforma agrária, as Áreas de Preservação Permanente (APP) e de Reserva Legal $(R L)$ representam um desafio para as famílias, uma vez que precisam conciliar suas atividades produtivas com a conservação dos recursos naturais da área. A legislação ambiental brasileira (Lei 12.651 de 25 de maio de 2012) estabelece que toda propriedade rural, inclusive assentamentos rurais da reforma agrária, devem manter ou recompor pelo menos $20 \%$ de sua área com cobertura de vegetação nativa a título de Reserva Legal. As RLs têm a função de assegurar o uso econômico de modo sustentável dos recursos naturais do imóvel rural, auxiliar a conservação e a reabilitação dos processos ecológicos e promover a conservação da biodiversidade, bem como o abrigo e a proteção de fauna silvestre e da flora nativa. A legislação ambiental estabelece ainda as extensões florestais, nativas ou não, denominadas de Áreas de Preservação Permanentes que devem ser preservadas ou recompostas nas margens de rios, lagos e lagoas naturais e artificiais, nascentes d’água, veredas, áreas de restinga, dunas e manguezais, topos de morros, montes e serras, em encostas com declividade superior a $45^{\circ}$, nas escarpas e nas bordas dos tabuleiros e chapadas, e em regiões com altitude superior a $1.800 \mathrm{~m}$. Estas áreas têm a função ambiental de preservar os recursos hídricos, a paisagem, a estabilidade geológica e a biodiversidade, facilitar o fluxo gênico de fauna e flora, proteger o solo e assegurar o bem-estar das populações humanas. A legislação também estabelece quais os tipos de atividades produtivas permitidas ou não de serem desenvolvidas nas APPs e RLs. No entanto, devido à intensa ocupação humana em áreas rurais e às dificuldades de fiscalização por parte dos órgãos ambientais, essas obrigações legais em relação a exploração e conservação das RLs e APPs geralmente não são cumpridas (ROCHA et al., 1998; FILHO et. al., 2007).

Um problema em torno da implementação das APPs e RLs é a ausência de incentivos econômicos e fiscais para a recuperação e conservação dessas áreas. Por outro lado, a fiscalização e a coerção, por parte do poder público não têm se mostrado suficiente para o cumprimento da legislação pelos proprietários rurais. No caso dos pequenos 
agricultores familiares, o problema é ainda maior em função da pouca disponibilidade de área para produção e ao fato de que a maioria dessas áreas apresentam graves problemas ambientais, sejam aqueles ocasionados por atividades monocultoras e de pecuária extensiva desenvolvidas previamente à fundação dos assentamentos ou aqueles provocados pelas atividades das fazendas ao redor (FILHO et. al., 2007; HADDAD; PEDLOWSKI, 2009; TERRA, 2009; STRECK; ESSI, 2013; ALMEIDA et al., 2020). Essas restrições são geralmente apontadas pelos pequenos produtores rurais como justificativas para o desenvolvimento de atividades produtivas em áreas de $R L$ e APP (STRECK; ESSI, 2013). Além disso, muitos pequenos produtores rurais têm dúvidas sobre diversos pontos da legislação ambiental no que se refere à exploração e conservação das RLs e APPs, particularmente em função das alterações dadas pela Lei 12.651 de 2012 e que estabeleceu o Novo Código Florestal Brasileiro (STRECK; ESSI, 2013; CAVALCANTE et al., 2019).

A Educação Ambiental se destaca como uma ferramenta conscientizadora importantíssima para a comunidade (ARGEL DE OLIVEIRA, 1996; JACOBI, 2003; COSTA, 2007; SOUZA et al., 2011; ALLENSPACH; ZUIN, 2013). Através dela é possível também avaliar a percepção ambiental dos moradores locais de forma que se sensibilizem para a importância da conservação e uso equilibrado dos recursos naturais no ambiente onde vivem e produzem seu alimento. É importante que as famílias se enxerguem como protagonistas e responsáveis pela preservação ambiental e que compreendam a importância de adotarem práticas produtivas adequadas à conservação da natureza (JACOBI, 2003; SOUZA et al., 2011). Esse trabalho teve como objetivo investigar o uso e conservação das áreas de Preservação Permanente e de Reserva Legal demarcadas no Assentamento Boa Vista, município de Ponta Porã, Mato Grosso do Sul. Avalia também o uso de agrotóxicos pelas famílias e em quais atividades produtivas eles são empregados. Através da apresentação de um cartaz com informações sobre a legislação referente a exploração e conservação das áreas de RL e APP, objetiva-se sensibilizar e conscientizar os moradores sobre a importância da conservação da natureza no assentamento.

\section{MATERIAL E MÉTODOS}

\section{Local de estudo}

O trabalho foi realizado no Assentamento Boa Vista $\left(22^{\circ} 0^{\prime} 40.83^{\prime \prime S}\right.$; 55 $46^{\prime} 19.86^{\prime \prime} \mathrm{O}$, elevação $650 \mathrm{~m}$ ), localizado no munícipio de Ponta Porã, MS (Figura 1). O local de estudo foi selecionado pois o primeiro autor era morador do assentamento durante a pesquisa e se inquietou com as irregularidades no uso das áreas de preservação permanentes e de reserva e legal por alguns moradores do assentamento. O estudo tem atributos, portanto, da pesquisa participante. $O$ assentamento foi fundado em 7 de fevereiro 2000 e nele residem 70 famílias oriundas da agricultura familiar (PIRES, 2002). Está situado na região sul do Estado de Mato Grosso do Sul, a cerca de 200 km da capital estadual Campo Grande. O clima da região de Ponta Porã é do tipo Cwa, ou seja, subtropical com inverno seco (com temperaturas inferiores a $18^{\circ} \mathrm{C}$ ) e verão quente (com temperaturas superiores a $22^{\circ} \mathrm{C}$ ) de acordo com classificação de 
Köppen (GONÇALVES et al., 2006). A temperatura média anual é de $21^{\circ}$ e a precipitação pluviométrica de $1.674 \mathrm{~mm}$.
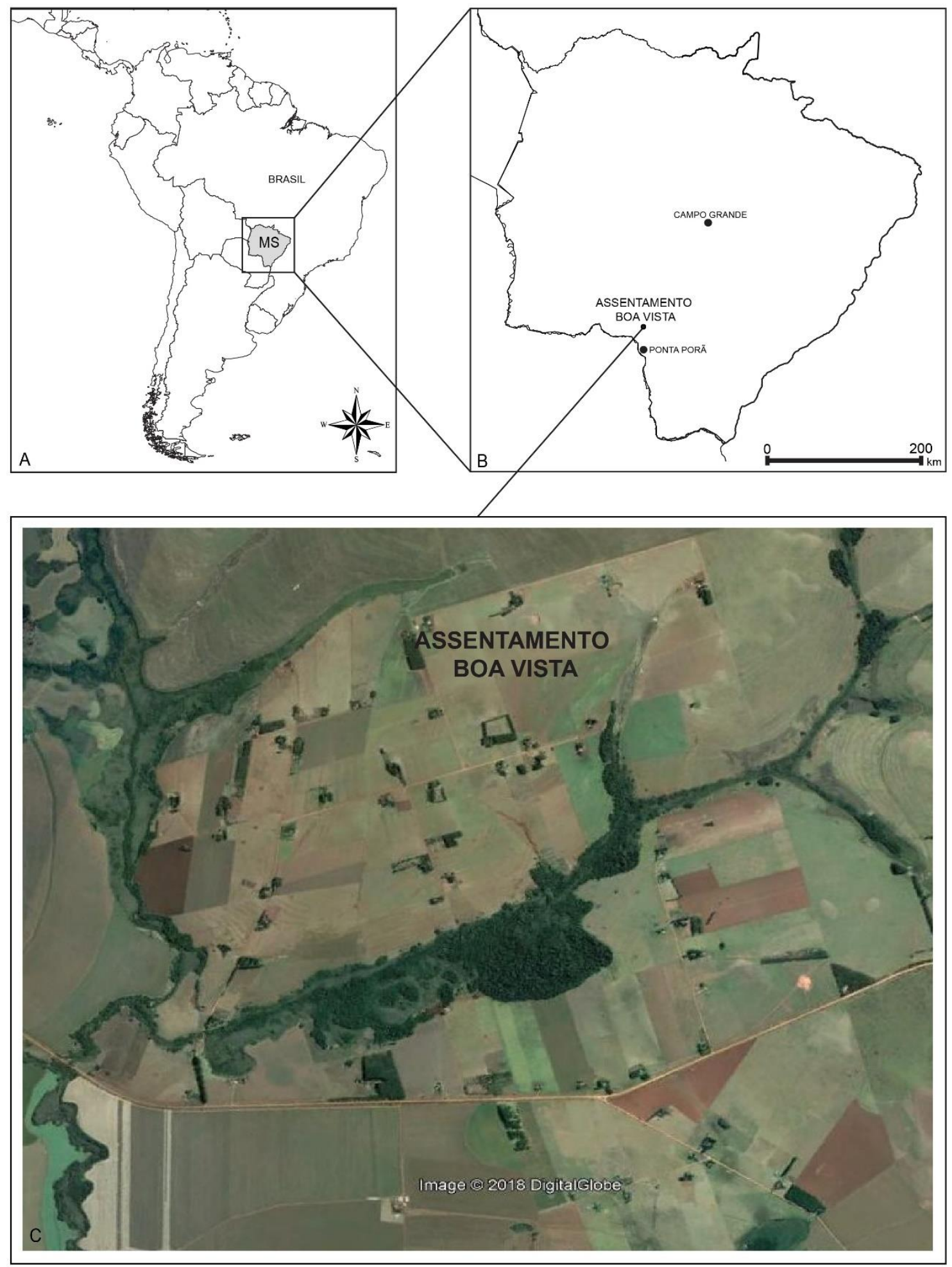

Figura 1. Localização do Assentamento Boa Vista, município de Ponta Porã, Mato Grosso do Sul. Fonte: Google Earth, elaborado pelos autores (2018). 
O assentamento apresenta um mosaico de fitofisionomias típicas de Mata Atlântica (Floresta Estacional Semidecidual) e de Cerrado, compreendidos por seis fragmentos florestais com diferentes estados de conservação e que constituem as seis áreas de Reserva Legal (RL) do assentamento (Figura 2). As seis reservas ocupam uma área de 423 ha, compreendendo $21 \%$ dos 2.050 ha de área total do assentamento (PIRES, 2002). Outras formações florestais do assentamento incluem matas ciliares e matas de entorno de nascentes, que compreendam as Áreas de Preservação Permanentes (APP) do local, com área total de 84ha (Figura 2). O assentamento é margeado a noroeste pelo córrego Pedra Branca e na porção sudeste pelo córrego Água Azul. O córrego Vista Alegre e o córrego Boa Vista atravessam o assentamento, sendo que duas nascentes desse último se localizam dentro do perímetro do assentamento. Dos 70 lotes do assentamento, apenas 13 não fazem contato direto com áreas de RL ou APP (Figura 2).

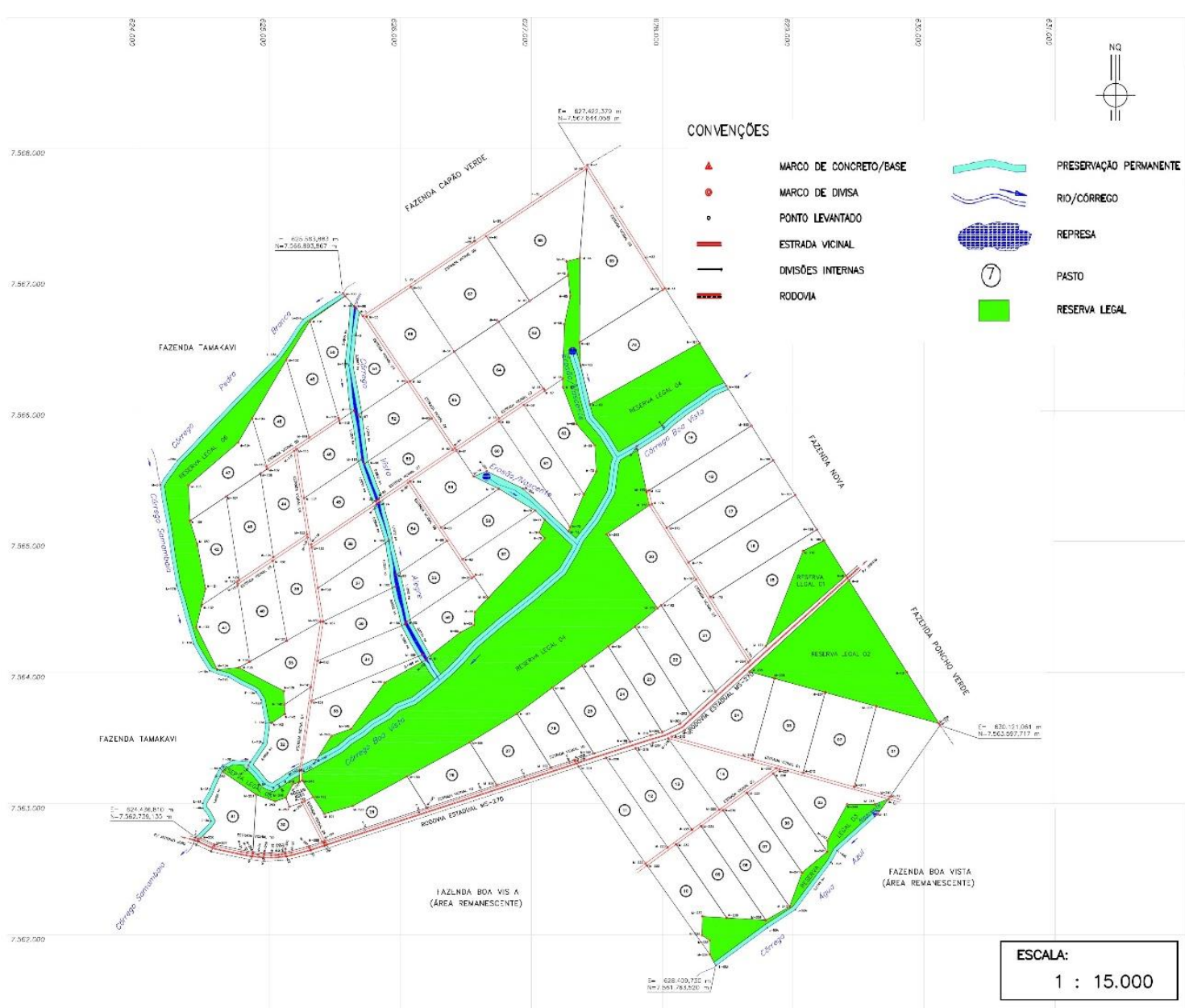

Figura 2. Mapa do Assentamento Boa Vista, Ponta Porã, Mato Grosso do Sul. Fonte: INCRA (2018). 
USO E CONSERVAÇÃO DAS ÁREAS DE PRESERVAÇÃO PERMANENTE E DE RESERVA LEGAL POR MORADORES DO ASSENTAMENTO BOA VISTA, PONTA PORÃ, MS

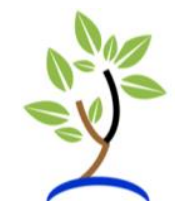

\section{Entrevista com os moradores}

Com o intuito de obter informações sobre o uso e conservação das áreas de Reserva Legal e de Preservação Permanente no Assentamento Boa Vista, foi elaborada uma pesquisa de campo baseada em um questionário semiestruturado composto por 24 questões. As visitas aos moradores foram realizadas entre os meses de janeiro e maio de 2018. As entrevistas serviram como base para o início de diálogos que contribuíram para o conhecer melhor os problemas socioambientais do assentamento. Em momentos específicos de cada entrevista foi entregue e debatido com os moradores um cartaz com informações básicas sobre as definições legais das áreas de RL e APP e com orientações sobre as atividades produtivas permitidas de serem realizadas nessas áreas com base na legislação ambiental brasileira vigente.

\section{RESULTADOS}

No estudo foram entrevistados moradores de 26 lotes, compreendendo $37 \%$ dos 70 lotes existentes no Assentamento Boa Vista. Dos 26 moradores entrevistados, apenas $7(27 \%)$ afirmaram que suas propriedades estão inscritas no Cadastro Rural Ambiental (CAR). Dezoito moradores (69\%) afirmaram que são os primeiros proprietários e que conquistaram o lote na data de fundação do assentamento. O restante dos moradores $(8 / 26,31 \%)$ afirmaram que compraram o lote, sendo que $19 \%(4 / 26)$ são os segundos proprietários, $12 \%(3 / 26)$ os terceiros, e um morador (4\%) afirmou ser o quarto proprietário do lote.

\section{Uso e conservação da RL e APP}

Quando questionados se sabem o que são áreas de reserva legal $(R L)$ e áreas de preservação permanentes (APPs), 65\% dos moradores (17/26) disseram que sim e $34 \%(9 / 26)$ não sabem exatamente o que é ou não sabem diferenciar uma da outra. Neste momento foi apresentado e debatido com o morador o cartaz com explicações sobre as definições e caracterizações da RL e APP. Cerca de $38 \%(10 / 26)$ dos entrevistados afirmaram que sua propriedade faz contato com RL e APP, $23 \%(6 / 26)$ disseram que apenas com RL, $8 \%$ (2/26) que faz contato apenas com APP e $31 \%$ (8/26) afirmaram que a propriedade não faz contato com nenhuma área de proteção ambiental (Figura 3A). Oito moradores (31\%) afirmaram que há nascente de água em sua propriedade e em apenas dois desses lotes elas estão cercadas apropriadamente para impedir o acesso do gado e outros animais. Dezesseis proprietários (62\%) afirmaram saber da existência de nascentes no assentamento como um todo, ao passo que 38\% (10/26) disseram não saber se há ou não nascentes de água no assentamento.

Quando questionados se tem conhecimento de quais atividades produtivas são permitidas de serem desenvolvidas nas áreas de RL e APP, a maioria (19/26, 73\%) afirmou não saber. Cerca de metade dos moradores (12/26, 46\%), afirmou que não 
desenvolve nenhum tipo de atividade produtiva em áreas de RL ou APP. Os outros 14 moradores (54\%) afirmaram desenvolver algum tipo de atividade nessas áreas, sendo que a apicultura foi apontada por 7 (27\%), a agricultura por um (4\%), e seis (23\%) não indicaram qual atividade produtiva desenvolvem em áreas de RL e APP (Figuras 3B). Quando questionados sobre quais os motivos que os levaram a produzir nessas áreas, a maioria (10/26, 38\%) apontou a área disponível para produção insuficiente como motivação. Dois moradores (8\%) apontaram como justificativa o fato de julgarem essas áreas improdutivas e outros dois moradores não quiseram dizer os motivos. Neste momento foi apresentado e debatido com o entrevistado o cartaz com explicações sobre as atividades produtivas permitidas ou não de serem desenvolvidas nas áreas de RL e APP. As áreas de RL e/ou APP que fazem contato com o lote estão apropriadamente cercadas de acordo com 57\% (15/26) dos moradores. A figura 4 mostra uma área preparada para o cultivo de soja em um lote arrendado para terceiros. A área faz contato direto com uma das reservas legais do assentamento e não se encontrava cercada durante o estudo. A Figura 5 mostra um dos marcos, arrancados pelos moradores que delimitava uma parte da Reserva Legal onde havia um grande guaviral e que foi desmatado e gradeado para o plantio de soja e posteriormente usado para plantio de pastagens para criação de gado, de acordo com moradores vizinhos.

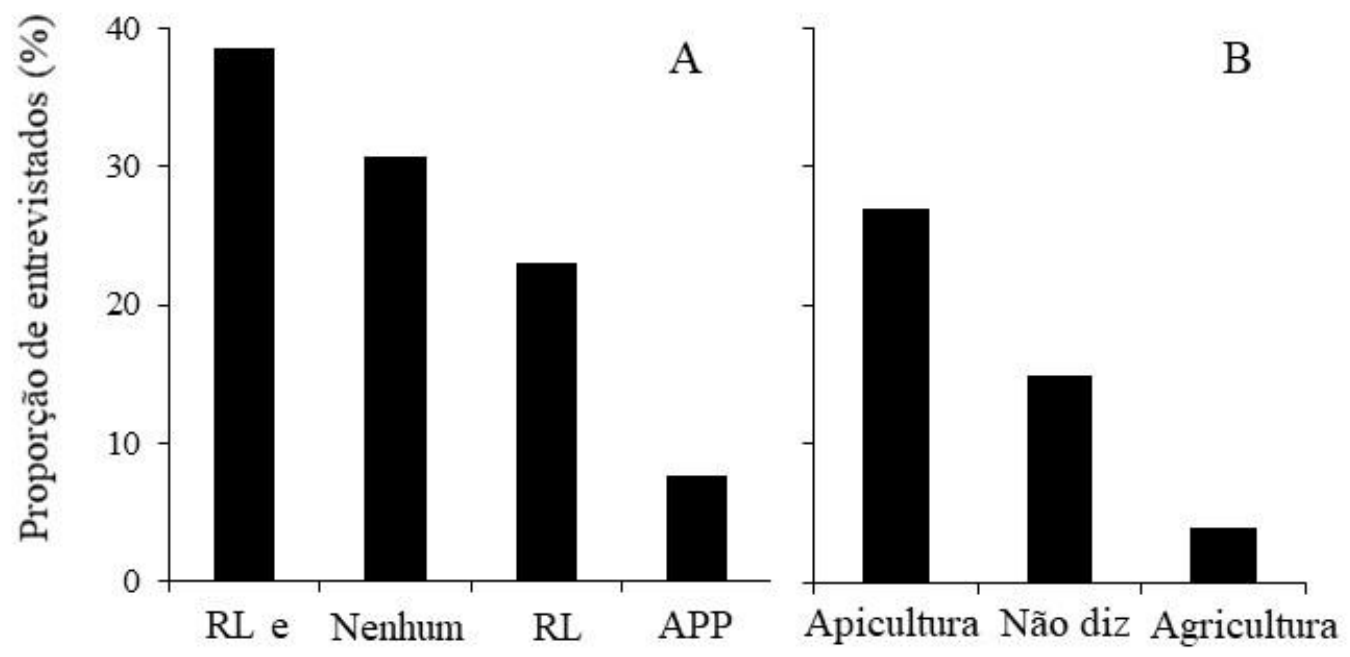

Figura 3. Proporção de moradores que afirmaram que sua propriedade faz contato com áreas de reserva legal $(R L)$ e áreas de proteção permanentes (APP), que não faz nenhum contato, que faz contato apenas com $R L$ e que faz contato apenas com APP (A) e atividades produtivas desenvolvidas em áreas de RL e APP (B) no Assentamento Boa Vista, município de Ponta Porã, Mato Grosso do Sul. Fonte: trabalho de campo, elaborado pelos autores (2020). 
USO E CONSERVAÇÃo DAS ÁREAS DE PRESERVAÇÃo PERMANENTE E DE RESERVA LEGAL POR MORADORES DO ASSENTAMENTO BOA VISTA, PONTA PORÃ, MS
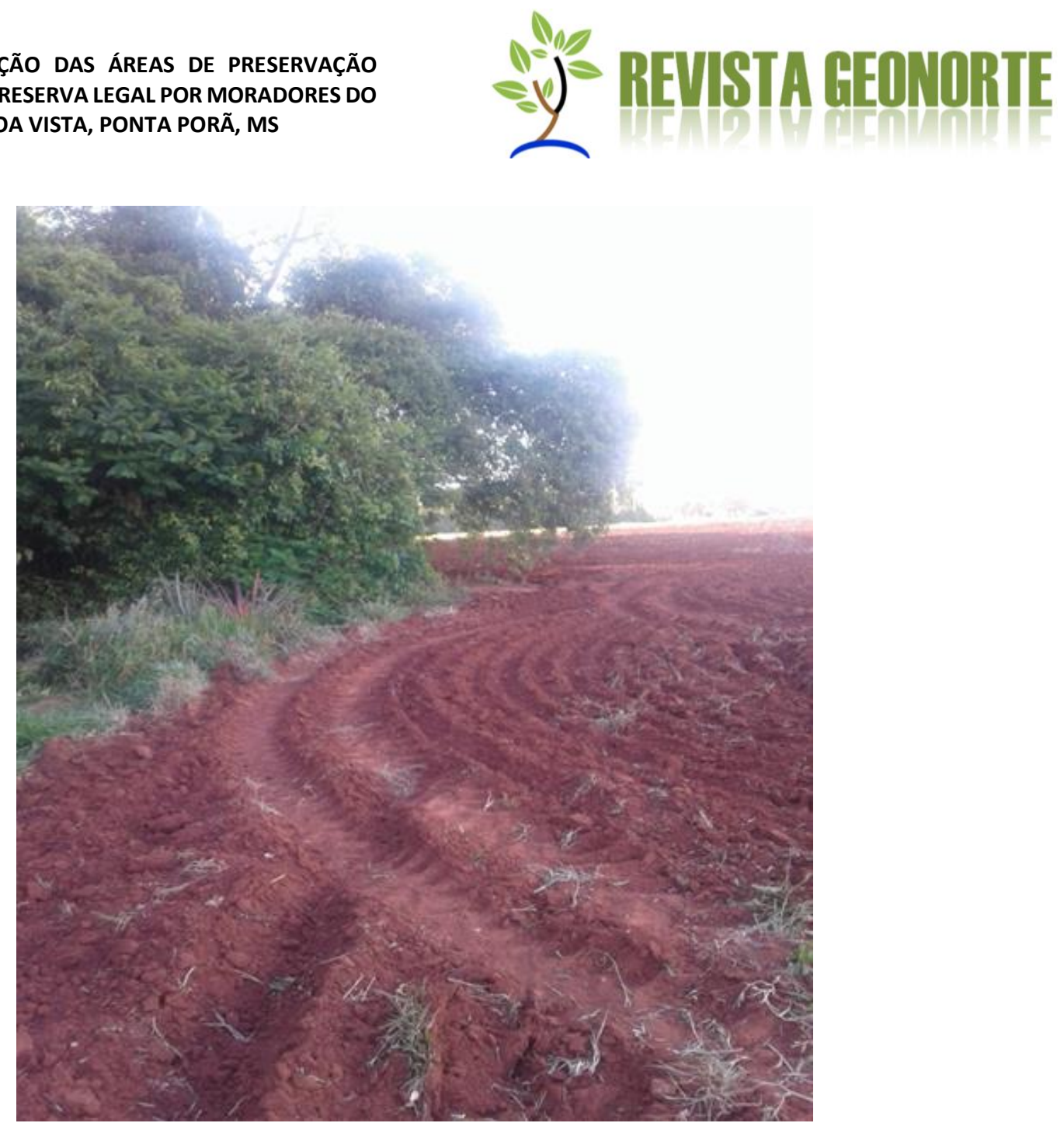

Figura 4. Área arrendada para terceiros, não cercada, de lote que faz contato com uma das reservas legais e preparada paro o cultivo de soja, no Assentamento Boa Vista, município de Ponta Porã, MS. Fonte: trabalho de campo (2018).

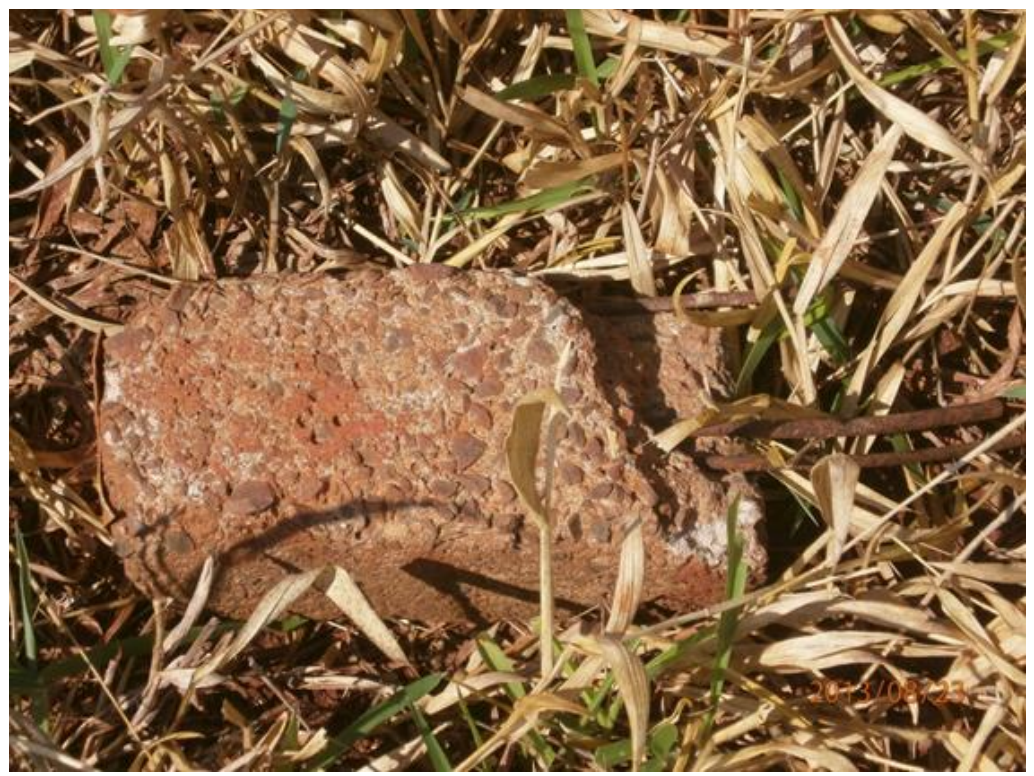

Figura 5. Um dos marcos de reserva legal arrancado por moradores do Assentamento Boa Vista, município de Ponta Porã, MS. Fonte: trabalho de campo (2018). 


\section{Atividades produtivas e o uso de agrotóxicos e fertilizantes}

Quando questionados sobre quais atividades produtivas eles consideram que ocupam a maior área do assentamento, a maioria afirmou ser a monocultura da soja, ao passo que $16 \%$ (4/26) afirmaram ser a produção diversificada e para dois moradores (8\%) que as duas formas de produção ocupam áreas iguais no assentamento. Nove dos 26 moradores (35\%) afirmaram que arrendam a maior parte de seu lote, sendo que $27 \%$ (7/26) dos proprietários arrendam para produtores de soja e 8\% (2/26) arrendam para criadores de gado (Figura 6).

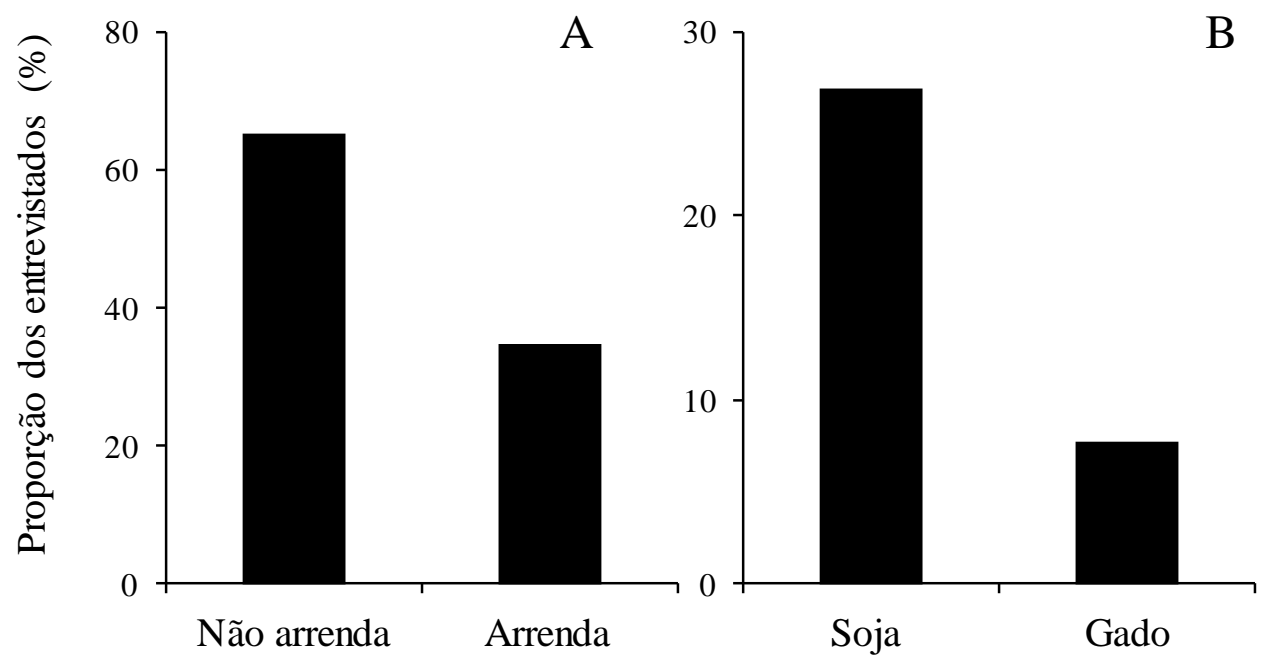

Figura 6. Proporção de moradores que afirmaram que não arrendam ou arrendam parte da área de seus lotes $(A)$ e atividades produtivas desenvolvidas nas áreas arrendadas (B) no Assentamento Boa Vista, município de Ponta Porã, Mato Grosso do Sul. Fonte: trabalho de campo, elaborado pelos autores (2020).

Uma parte significativa dos proprietários (11/26, 42\%) afirmou que utiliza algum tipo de agrotóxico nas atividades produtivas desenvolvidas no lote (Figura 7A). O uso de agrotóxicos no cultivo da soja foi apontado por $31 \%(8 / 26)$ dos moradores, ao passo que dois moradores (8\%) afirmaram usar inseticidas e carrapaticidas na criação do gado e dois (8\%) não informaram em qual atividade empregam agrotóxicos (Figura 7B). O agrotóxico mais utilizado foi o glifosato, empregado em todos os lotes que possuem o cultivo da soja (Figura 7C). Um morador afirmou que usa dessecantes não especificados, e outro utiliza fungicidas (Trifloxistrobina e Protioconazole, componentes ativos do Fox da Bayer), ambos empregados no cultivo da soja. Um morador afirmou usar pesticidas não especificados em combinação com o glifosato no cultivo da soja (Figura 7C). O uso de fertilizantes químicos industrializados foi apontado por 54\% (14/26) dos moradores (Figura 8A). Os fertilizantes são empregados principalmente no cultivo da soja, apontado por $27 \%$ (7/26) dos moradores. Também são utilizados em outras culturas, como tomate, milho, cebola, alho, plantas frutíferas e nas hortas (Figura 8B). 

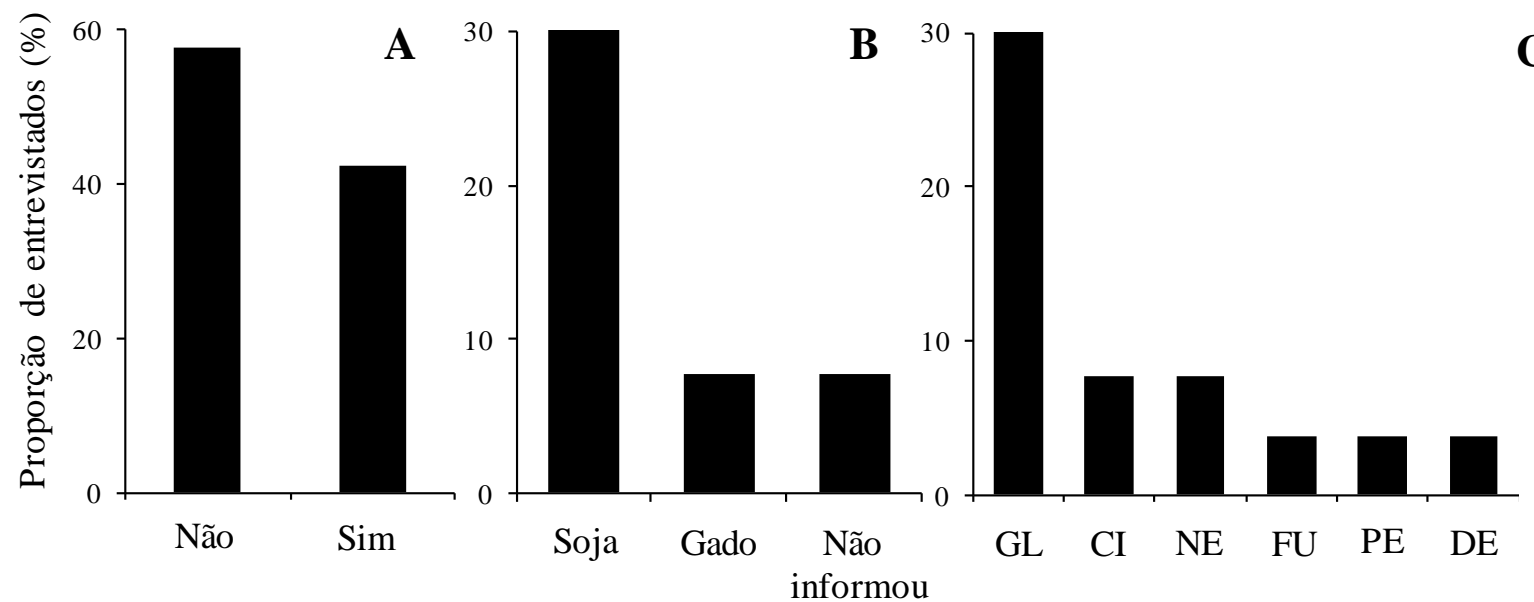

Figura 7. Proporção de moradores que afirmaram usar ou não agrotóxicos nas atividades produtivas do lote $(A)$, atividades produtivas em que os agrotóxicos são empregados $(B)$, e tipos de agrotóxicos empregados (C), no Assentamento Boa Vista, município de Ponta Porã, Mato Grosso do Sul. GL: glifosato, Cl: carrapaticida e inseticida não especificados usados na criação do gado, NE: agrotóxicos não especificados, FU: fungicida (Trifloxistrobina e Protioconazole, componentes ativos do Fox da Bayer), PE: pesticida não especificado, DE: dessecante não especificado. Fonte: trabalho de campo, elaborado pelos autores (2020).
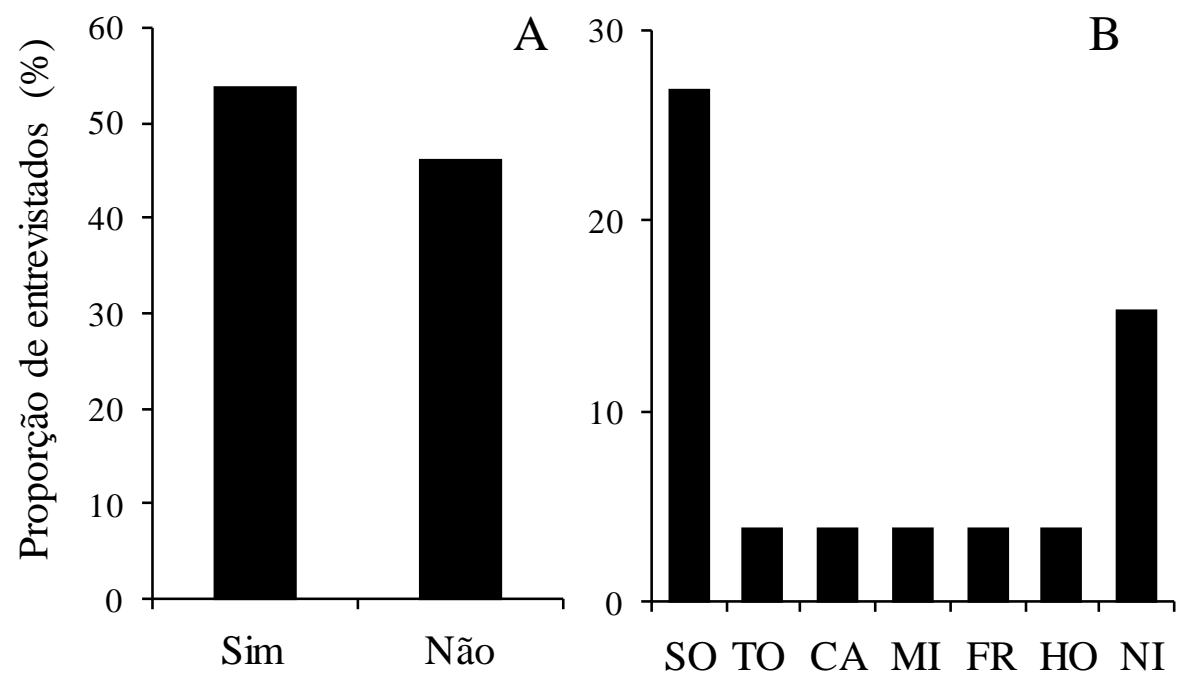

Figura 8. Proporção de moradores que afirmaram usar ou não fertilizantes químicos industrializados nas atividades produtivas do lote $(A)$ e atividades produtivas em que os agrotóxicos são empregados (B), no Assentamento Boa Vista, município de Ponta Porã, Mato Grosso do Sul. SO: soja, TO: tomate, CA: cebola e alhoa, MI: milho, FR: frutíferas, HO: horta, $\mathrm{NI}$ : não informou. Fonte: trabalho de campo, elaborado pelos autores (2020). 
Quando questionados se desenvolvem atividades produtivas consideradas de baixo impacto ambiental, 62\% (16/26) afirmaram que sim (Figura 9). Horta orgânica (7/26, $27 \%$ ) e o emprego de biofertilizantes $(6 / 26,23 \%)$ foram as atividades de baixo impacto mais citadas pelos moradores. Sessenta e dois porcento (16/26) dos moradores afirmaram que praticam atividades produtivas consideradas de alto impacto ambiental, sendo que a mais citada foi o cultivo da soja, apontada por 35\% (9/26) dos entrevistados (Figura 10). Quando questionados se tinham conhecimento da ocorrência de problemas ambientais no lote ou assentamento, a contaminação do solo, lençol freático e águas superficiais por fertilizantes e/ou agrotóxicos foi o problema mais citado pelos moradores entrevistados (15/26, 58\%) (Figura 11).

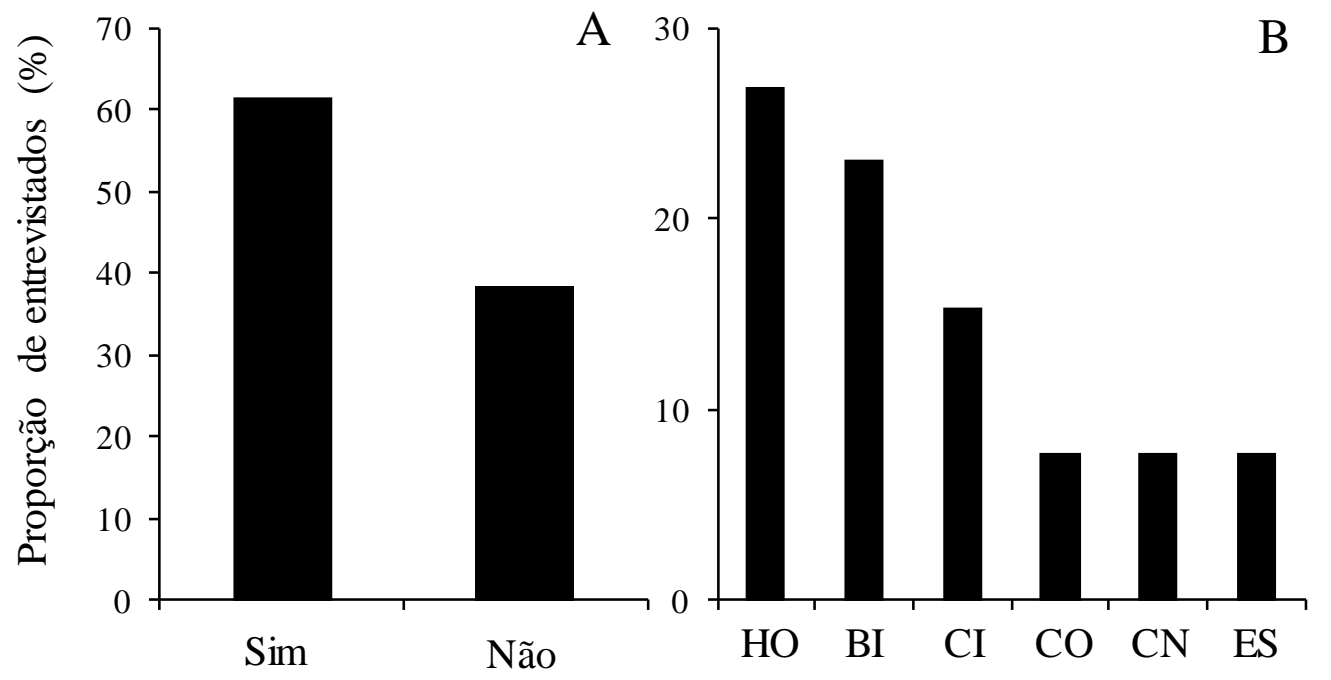

Figura 9. Proporção de moradores que afirmaram ou não desenvolver atividades consideradas de baixo impacto ambiental $(A)$ e atividades produtivas consideradas de baixo impacto ambiental desenvolvidas pelos moradores (B), no Assentamento Boa Vista, município de Ponta Porã, Mato Grosso do Sul. HO: horta orgânica, BI: emprego de biofertilizantes, $\mathrm{Cl}$ : cisternas ou sistemas de reaproveitamento de água, $\mathrm{CO}$ : compostagem, $\mathrm{CN}$ : emprego de curvas de nível, ES: uso de esterco para adubação. Fonte: trabalho de campo, elaborado pelos autores (2020). 


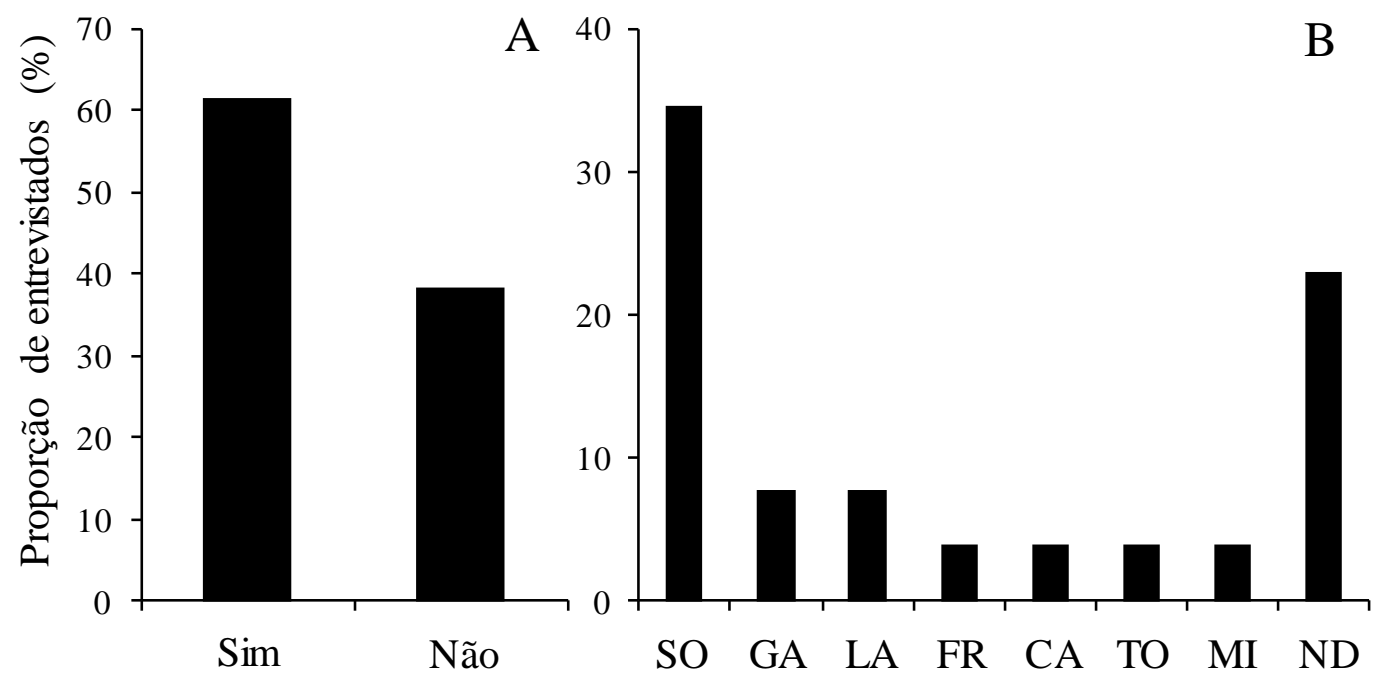

Figura 10. Proporção de moradores que afirmaram ou não desenvolver atividades consideradas de alto impacto ambiental (A) e atividades produtivas consideradas de alto impacto ambiental desenvolvidas pelos moradores (B), no Assentamento Boa Vista, município de Ponta Porã, Mato Grosso do Sul. SO: soja com emprego agrotóxicos e fertilizantes químicos industrializados, GA: criação de gado, LA: lavoura não especificada, FR: frutíferas com emprego de agrotóxico, CA: cebola e alho com emprego de fertilizantes químicos industrializados, TO: tomate com emprego de fertilizantes químicos industrializados, MI, milho com emprego de fertilizantes químicos industrializados, ND: não quis dizer. Fonte: trabalho de campo, elaborado pelos autores (2020).

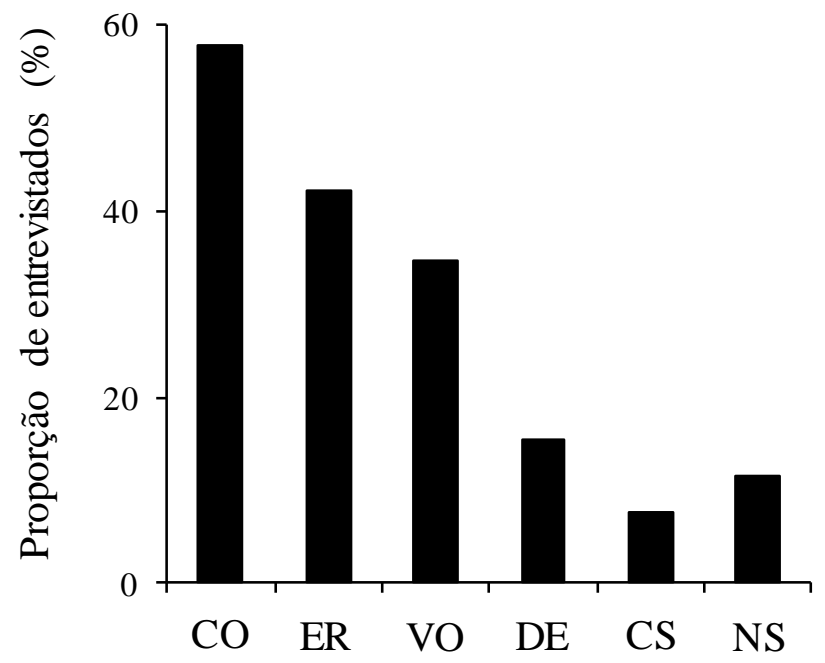

Figura 11. Problemas ambientais que ocorrem no lote e/ou assentamento apontados pelos moradores do Assentamento Boa Vista, município de Ponta Porã, Mato Grosso do Sul. CO: contaminação do solo, lençol freático e águas superficiais por fertilizantes e/ou agrotóxicos, ER: erosão, VO: voçoroca, DE: desmatamento, CS: compactação do solo, NS: não sabe. Fonte: trabalho de campo, elaborado pelos autores (2020). 
USO E CONSERVAÇÃO DAS ÁREAS DE PRESERVAÇÃO PERMANENTE E DE RESERVA LEGAL POR MORADORES DO ASSENTAMENTO BOA VISTA, PONTA PORÃ, MS

\section{Políticas de conscientização sobre a conservação da natureza}

A maioria dos moradores (20/26, 76\%) afirmou que nunca recebeu nenhuma orientação sobre as atividades produtivas que são permitidas em áreas de RL e APP. Dentre os seis moradores que afirmaram ter recebido orientações, quatro (15\%) disseram que foram orientados pelo IBGE, um pelo INCRA e outro pelo IBAMA e pesquisadores de universidades logo no início da fundação do assentamento. Além disso, a maioria dos proprietários (22/26, 85\%) afirmou que não houve atividades de conscientização da importância da conservação da natureza no assentamento. A maioria dos proprietários $(23 / 26,88 \%)$ afirmou que nunca recebeu a visita de órgãos de fiscalização ambiental em seu lote. A maioria $(21 / 26,81 \%)$ considera que seria importante a visita de órgãos de fiscalização ambiental no assentamento. Quando questionados se sabiam que podiam obter informações sobre a legislação ambiental na Secretaria Municipal de Desenvolvimento Sustentável e Meio Ambiente de Ponta Porã, a maioria (25/26, 96\%), afirmou que não sabia dessa informação.

\section{DISCUSSÃO}

Os resultados do estudo mostram que a maioria dos moradores entrevistados (73\%) não regularizaram suas propriedades através da inscrição no Cadastro Ambiental Rural (CAR). A Lei no 12.651 de 2012 passou a exigir o registro no CAR de todas as propriedades rurais. No caso dos assentamentos rurais da reforma agrária, o INCRA é responsável pela inscrição de cada lote individualmente e o processo não tem nenhum custo às as famílias. A inscrição no CAR é importante do ponto de vista socioambiental, pois assegura aos assentados 0 acesso aos créditos agrícolas a outras políticas públicas (ZENATTI; CAMACHO, 2019), além de promover a regularização das áreas de Reserva Legal $(R L)$ e de Preservação Permanente (APP). No caso do Assentamento Boa Vista a regularização das RLs e APPs promovidas pela inscrição no CAR é particularmente importante, uma vez que a maioria dos lotes (57/70, 81\%) faz contato direto com áreas de RL e/ou APP (ver Figura 2). Apesar disso, uma parte significativa dos moradores (34\%) afirmou não saber o que são essas áreas, e $31 \%$ afirmaram que o seu lote não faz contato direto com nenhuma dessas áreas. Além disso, a maioria dos entrevistados (73\%) afirmou não saber quais as atividades produtivas permitidas por lei de serem desenvolvidas nessas áreas de preservação, semelhante ao registrado em outro assentamento do estado (CAVALCANTE et al., 2019). No entanto, mesmo sem esse conhecimento, uma parte significativa dos moradores (54\%) afirmou que desenvolve algum tipo de prática produtiva nessas áreas, e em pelo menos e uma das propriedades (4\%), essa atividade é irregular (agricultura) e presume-se que também o seja em outras seis propriedades cujos moradores se recusaram a informar as atividades desenvolvidas. O principal motivo apontado pelos moradores para o desenvolvimento de atividades produtivas nessas áreas restritas é a insuficiência de área para a produção nos lotes, como também verificado em outros assentamentos do país (STRECK; ESSI, 2013). Esses resultados reforçam a importância da necessidade da adoção de práticas produtivas que resultem em uma maior produtividade por hectare, diminuindo assim a 
necessidade de exploração de áreas de proteção ambiental nos assentamentos. Para tanto, é essencial que os assentados recebam assistência de instituições governamentais e não governamentais com o objetivo de se estabelecer uma agricultura familiar mais rentável, com bases agroecológicas e de baixo impacto ambiental (CAMACHO, 2015; ALMEIDA et al., 2020). Essa assistência é ainda mais importante quando se considera que o assentamento foi estabelecido em uma região historicamente dominada pela produção de soja, o que resultou em uma intensa degradação ambiental (PIRES, 2002; TERRA, 2009). Além disso, os resultados indicam a necessidade de realização de atividades de orientação e conscientização sobre a exploração e conservação de recursos naturais junto aos moradores de assentamentos rurais (HADDAD; PEDLOWSKI, 2009; STRECK; ESSI, 2013, CAVALCANTE et al., 2019). De fato, a maioria dos moradores afirmou nunca ter recebido nenhuma orientação sobre quais as atividades produtivas permitidas nas áreas de RL e APP, tampouco que não houve atividades de conscientização sobre a importância da conservação da natureza no assentamento.

Os resultados evidenciam uma política falha de fiscalização e coerção por parte dos órgãos ambientais, visto que a maioria dos proprietários (88\%) afirmaram que nunca recebeu visitas de nenhum órgão de fiscalização ambiental. Para a maioria dos moradores uma fiscalização eficaz seria importante para a conservação dos recursos naturais do assentamento, uma vez que coibiria muitas das práticas irregulares, como o avanço da agricultura nas RLs e APPs. Nota-se que a maioria dos moradores foi capaz de identificar vários problemas ambientais presentes no assentamento, com destaque para a preocupação com a contaminação do solo, do lençol freático e das águas superficiais com agrotóxicos e fertilizantes no assentamento, um problema comum apontado pelos moradores. Essa percepção ambiental por parte dos moradores constitui um passo importante no sentido de se enxergarem como protagonistas responsáveis pela recuperação e manutenção do equilíbrio ecossistêmico do ambiente onde vivem e produzem seu alimento (JACOBI, 2003; HADDAD; PEDLOWSKI, 2009; SOUZA et al., 2011; STRECK; ESSI, 2013, CAVALCANTE et al., 2019).

Uma situação grave registrada no estudo é o arrendamento de parte das áreas dos lotes para produtores de soja e criadores de gado, prática adotada por $35 \%$ dos entrevistados no Assentamento Boa Vista. Apesar de ser ilegal, o arrendamento de áreas em assentamentos é uma prática comum, sendo registrada em vários assentamentos do Mato Grosso do Sul e do Brasil (TERRA, 2009; ZENATTI; CAMACHO, 2019). O arrendamento é uma prática incoerente com os objetivos da reforma agrária, pois de acordo com Martins (2003, p.109) "contraria completamente a ideologia de valorização do trabalho enquanto meio legítimo de inserção e participação social, que é a ideologia dos que combatem a exclusão social e se batem pela reforma agrária". Endividamento, dificuldade de obtenção de crédito e dificuldades técnicas para trabalhar a terra são as principais justificativas apontadas pelas famílias assentadas para 0 arrendamento (TERRA, 2009; ZENATTI; CAMACHO, 2019; ALMEIDA et al. 2020). Apesar da renda mensal decorrente dos arrendamentos ser providencial para os assentados, muitos não se dão conta que essa prática resultará no esgotamento de nutrientes da terra, compactação do solo, 
contaminação do solo, lençol freático e dos corpos d’água com agrotóxicos e fertilizantes, entre outros fatores de degradação ambiental que futuramente dificultarão a produção de alimento pelas famílias. Além disso, os valores recebidos pelo arrendamento são muito baixos, principalmente quando se leva em conta os impactos socioambientais dessa prática. Como vimos no estudo, todos os assentados que produzem soja no assentamento utilizam agrotóxicos, sendo o glifosato o mais comum. O uso de agrotóxicos na produção de alimentos é indubitavelmente danoso ao funcionamento dos ecossistemas e à saúde humana (GRAYMORE et al., 2001; RELYEA, 2005; BEKETOV et al., 2013; BELCHIOR et al., 2017; AMÉRICO et al., 2015; NEWMAN et al., 2016). Do ponto de vista social, a produção de commodities e o desenvolvimento de outras atividades produtivas com alto impacto ambiental podem gerar atritos e desgastes entre aqueles moradores contra e a favor do desenvolvimento dessas práticas produtivas. A produção de monoculturas submete as famílias assentadas ao modelo perverso do agronegócio, que é pautado na maximização dos lucros e no desprezo de relações socioambientais justas e equilibradas (CAMACHO, 2015, ALMEIDA et al., 2020). Portanto, a produção de soja pelas famílias somada à produção dos arrendatários, resulta em um cenário grave onde grandes extensões de terra do assentamento se destinam à produção de commodities com emprego de agrotóxicos e fertilizantes químicos industrializados, gerando um grande impacto socioambiental.

\section{CONCLUSÕES E CONSIDERAÇÕES FINAIS}

Os resultados do estudo evidenciam um cenário onde boa parte dos moradores produzem soja com o emprego de agrotóxicos ou arrendam parte da área de seus lotes para que terceiros a produzam. Este modelo do cultivo de monocultura coloca em risco a soberania alimentar da comunidade, uma vez que diminui drasticamente o espaço para o cultivo diversificado de alimentos saudáveis, livres de agrotóxicos. Além disso, gera fortes impactos ambientais, avançando sobre áreas de APP e RL, e reduz a biodiversidade local, prejudicando as funções ecossistêmicas do assentamento. Os resultados evidenciam a necessidade de sensibilizar a comunidade do assentamento sobre a importância da agricultura camponesa como sendo a principal forma de garantir a soberania alimentar que pode ser alcançada através de um modelo de produção agroecológica, pautado por relações justas e equilibradas entre as pessoas e destas com a natureza. Defendemos aqui que o modo de vida camponês deve ser tipicamente anticapitalista, fundamentado na produção para subsistência e na cooperação comunitária. Entendemos que o campesinato deve continuar se consolidando como um modo de vida não capitalista. Para tanto, é preciso colocar em prática a conservação ambiental, que tanta gente reivindica, mas que poucos se propõe a cumprir, reconhecendo as responsabilidades individuais e coletivas frente a essa questão. É imperativo o planejamento de ações por parte dos moradores do assentamento e através de políticas públicas por parte dos governos federais, estaduais e municipais que contribuam para transformações da qualidade de vida da comunidade, e o respeito à natureza é um paço fundamental para que esses objetivos sejam alcançados. 
USO E CONSERVAÇÃO DAS ÁREAS DE PRESERVAÇÃO PERMANENTE E DE RESERVA LEGAL POR MORADORES DO ASSENTAMENTO BOA VISTA, PONTA PORÃ, MS

\section{REFERÊNCIAS BIBLIOGRÁFICAS}

ALMEIDA, D. C.; CAMACHO, R. S.; CONCEIÇÃO, C. A. O impacto da monocultura da soja na agricultura camponesa: um estudo sobre as mudanças na produção de leite no Assentamento Itamarati I - FETAGRI/MS. Revista Geonorte, v.11, n.37, p.57$77,2020$.

AGROFIT. Sistema de Agrotóxicos Fitosanitários. Disponível em: $<$ http://agrofit.agricultura.gov.br/agrofit_cons/principal_agrofit_cons>. Acesso em: 26 de novembro de 2020.

ALLENSPACH, N.; ZUIN, P. B. Aves como subsídio para a Educação Ambiental: perfil das iniciativas brasileiras. Atualidades Ornitológicas On-line, v.176, p.50-57, 2013.

ALTIERI, M. A dinâmica produtiva da agricultura sustentável. Porto Alegre: Editora da UFRGS, 2004. 117 p.

AMÉRICO, J. H. P; MANOEL. L. O.; TORRES, N. H.; FERREIRA, L. F. R. O uso de agrotóxicos e os impactos nos ecossistemas aquáticos. Revista Científica ANAP Brasil, v.8, n.13, p.101-115, 2015.

ARGEL-DE-OLIVEIRA, M. M. Subsídios para a atuação de biólogos em Educação Ambiental. O uso de aves urbanas em Educação Ambiental. Mundo Saúde, v.20 n.8, p.263-270, 1996.

BEKETOV, M. A.; KEFFORD, B. J.; SCHÄFER, R. B.; LIESS, M. Pesticides reduce regional biodiversity of stream invertebrates. PNAS, v.110, n. 27, p.11039-11043, 2013.

BELCHIOR, D. C. V.; SARAIVA, A. S.; LÓPEZ, A. M. C.; SCHEIDT, G. N. Impactos de agrotóxicos sobre o meio ambiente e a saúde humana. Cadernos de Ciência \& Tecnologia, v.34, n.1, p.135-151, 2014.

CAMACHO, R. S. O Plano Camponês para a Soberania Alimentar e Energética numa perspectiva Agroecológica. Cadernos de Agroecologia, [S.I.], v. 9, n. 4, fev. 2015. Disponível em: <http://revistas.abaagroecologia.org.br/index.php/cad/article/view/16391>. Acesso em: 26 de novembro de 2020.

CAMACHO, R. S.; CUBAS, T. E.A. A recriação dos territórios camponeses por meio da produção de alimentos e energia: a experiência do MPA em Frederico WestphalenRS. Agrária, São Paulo, v.15, p.4-44, 2011.

CAVALCANTE, E. S.; GISLOTI, L. J.; STRONZAKE, J. Convivendo com a diversidade: a percepção camponesa sobre o impacto da fauna silvestre nas lavouras 
USO E CONSERVAÇÃO DAS ÁREAS DE PRESERVAÇÃO PERMANENTE E DE RESERVA LEGAL POR MORADORES DO ASSENTAMENTO BOA VISTA, PONTA PORÃ, MS

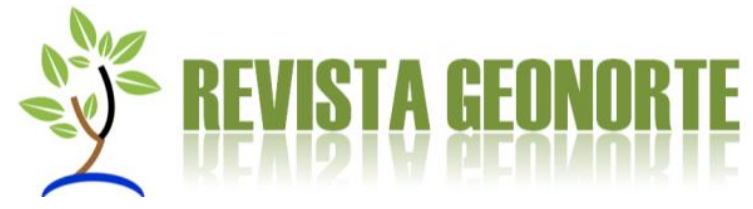

do Assentamento Colônia Nova, Nioaque, MS. Gaia Scientia, v.13, n.3, p.784-84, 2019.

COSMANN, N. J.; DRUNKLER, D. A. Agrotóxicos utilizados nas culturas de milho e soja em Cascavel-PR. Inovação e Tecnologia, v.2, n.6, p.15-32, 2012.

COSTA, R. G. A. Observação de aves como ferramenta didática para educação ambiental. Revista Didática Sistêmica, v.6, p.33-44, 2007.

CRESSEY, D. Widely used herbicide linked to cancer. Nature News. Disponível em: $<$ https://www.nature.com/news/widely-used-herbicide-linked-to-cancer-1.17181>, 2015. Acesso em: 26 de novembro de 2020.

FILHO, L. O. R.; FRANCISCO, C. E.; JUNIOR, O. A. Legislação ambiental e uso dos sistemas agroflorestais em assentamentos rurais no estado de São Paulo. Revista Brasileira de Agroecologia, v. 2, n. 1, p.280-283, 2007.

GONÇALVES, A. O.; PEREIRA, N. R.; COSTA, L. L. Caracterização climática e aptidão das culturas anuais e perenes no zoneamento pedoclimático do estado do Mato Grosso do Sul - 1a fase. Rio de Janeiro: Embrapa Solos. Boletim de pesquisa e desenvolvimento 99, 2006. 52 p.

GRAYMORE, M.; STAGNITTI, F.; ALLINSON, G. Impacts of atrazine in aquatic ecosystems. Environment International, v.26, p.483-495, 2001.

HADDAD, L. N.; PEDLOWSKI, M. A. Explorando a tensão entre proteção ambiental e reforma agrária: o caso das áreas de preservação permanente e de reserva legal do Assentamento Antônio de Farias, Campos dos Goytacazes, RJ. In: ENCONTRO NACIONAL DE GEOGRAFIA AGRÁRIA, 19., São Paulo, 2-7 de fevereiro de 2009. Anais... São Paulo: Editora da USP, 2009. p. 1-22.

JACOBI, P. Educação Ambiental, Cidadania e Sustentabilidade. Cadernos de Pesquisa, São Paulo, v.118, p.8-17, 2003.

MARTINS, J. S. O sujeito oculto: ordem e transgressão na reforma agrária. Porto Alegre: Editora da UFRGS, 2003, 240p.

NEWMAN, M. M.; HOILETT, N.; LORENZ, N; DICK, R. P.; LILES, M. R.; RAMSIER, C.; KLOEPPER, J. W. Glyphosate effects on soil rhizosphere-associated bacterial communities. Science of the Total Environment, v.543, p.155-160, 2016.

PETERSEN, P. Agriculturas alternativas. In: CALDART, R. S.; PEREIRA, I. B.; FRIGOTTO, P. A. G.; (Orgs.) Dicionário da Educação do Campo, Rio de Janeiro, São Paulo - Escola Politécnica de Saúde Joaquim Venâncio, Expressão Popular, 2012, p. $42-48$ 
USO E CONSERVAÇÃO DAS ÁREAS DE PRESERVAÇÃO PERMANENTE E DE RESERVA LEGAL POR MORADORES DO ASSENTAMENTO BOA VISTA, PONTA PORÃ, MS

PINTO, C. C.; OLIVEIRA, C. O.; AMÉRICO, G. H. P.; VAZQUEZ, G. H.; LAZARINI, E. Efeito da dose e da época de aplicação do glifosato na produção e na qualidade da soja RR. Revista de Ciências Agrárias, v.39, n.2, p.310-317, 2016.

PIRES, M. A. P. Diagnóstico sócio-econômico de assentamentos rurais na região de Ponta Porã e as perspectivas de desenvolvimento local. Dissertação (Mestrado em Desenvolvimento Local) - UCDB, Campo Grande, 2002.

RELYEA, R. A. The impact of insecticides and herbicides on the biodiversity and productivity of aquatic communities. Ecological Applications, v.15, n.2, p.618-627, 2005.

ROCHA, V. M.; CARVALHO, R. A.; SCHWARZ, C. O.; FERREIRA, A. P. M. Mapeamento da Cobertura Vegetal e Uso da Terra visando a Caracterização da Situação Legal da Vegetação no Projeto de Assentamento de um imóvel rural no Município de Presidente Olegário, MG. In: SIMPÓSIO BRASILEIRO DE SENSORIAMENTO REMOTO, 9., Santos, 11-18 de setembro de 1998. Anais... Santos: Editora do INPE, 1998. p. 1505-1515.

SANTOS, F. P.; CHALUB-MARTINS, L. Agroecologia, consumo sustentável e aprendizado coletivo no Brasil. Educação e Pesquisa, v.38, n.2, p. 469-483, 2012.

SOUZA, J. C. M.; GONÇALVES, L.; SOARES, A. M. D. A. Educação Ambiental na recuperação e conservação de recursos naturais: a percepção de assentados rurais no cerrado goiano. Revista de Geografia Agrária, v.6, n.11, p.312-337, 2011.

STRECK, M. T.; ESSI, L. Áreas de preservação permanente e reserva legal: experiência em educação ambiental envolvendo famílias de produtores rurais. Revista do Centro do Ciências Naturais e Exatas - UFSM, Santa Maria, v.14, n.14, p.28322838, 2013.

TERRA, A. Reforma agrária por conveniência e/ou por pressão? Assentamento Itamarati em Ponta Porã - MS: "o pivô da questão". Tese (Doutorado em Geografia) Faculdade de Ciências e Tecnologia, Universidade Estadual Paulista, Presidente Prudente, 2009.

ZENATTI, F. A.; CAMACHO, R. S. As dificuldades dos camponeses assentados de permanecer e produzir na terra em lotes irregulares no assentamento São Judas: uma análise sobre avanços e limites da reforma agrária. Fórum Ambiental da Alta Paulista, v.15, p.1-15, 2019. 